\title{
Effect of dietary organic selenium (Se) on immune response, hepatic antioxidant status, selenoprotein gene expression and meat oxidative stability in lambs
}

\author{
R.U. Suganthi ${ }^{1,3}$, J. Ghosh', P.K. Malik', V.B. Awachat', P. Krishnamoorthy' ${ }^{2}$, D.T. Pal' ${ }^{1}$ \\ and S.S. Nongkhlaw ${ }^{1}$ \\ ${ }^{1}$ ICAR-National Institute of Animal Nutrition and Physiology, Indian Council of Agricultural Research, \\ Adugodi, Bangalore, Karnataka 560030, India \\ ${ }^{2}$ ICAR-National Institute of Veterinary Epidemiology and Disease Informatics, Indian Council of Agricultural Research, \\ Bangalore, Karnataka 560 064, India
}

KEY WORDS: antioxidant status, gene expression, immune response, lambs, meat quality, selenium, yeasts

Received: $\quad 10$ July 2018

Revised: 15 December 2018

Accepted: $\quad 24$ May 2019

${ }^{3}$ Corresponding author:

e-mail: r.umayasuganthi@gmail.com

\begin{abstract}
The objective of the study was to examine the effects of different doses of dietary organic selenium (Se) on humoral immune response, hepatic antioxidant status, mRNA expression of key selenoproteins and oxidative stability of lamb meat. Twenty lambs aging 5-6 months received during a 90-day period a basal diet unsupplemented or supplemented with $0.5,1.5$ or $4.5 \mathrm{ppm}$ Se (selenized yeasts). After experimental period, immune response against Peste des petits ruminants (PPR) virus vaccine, hepatic antioxidant status, selenoproteins gene expression, histology of liver, kidney, spleen and thymus, and meat oxidative stability after $0,3,7$ and 10 days of storage were studied. Significantly higher serum PPR antibody titre and hepatic total antioxidant capacity in lambs fed diet supplemented with 1.5 and $4.5 \mathrm{ppm}$ Se were shown. Gene expression of glutathione peroxidase 1 (GPX1) and GPX3 was increased in group with 0.5 ppm Se supplementation. While selenoprotein 15 and iodothyronine deiodinase 1 (DIO1) mRNA levels were not influenced by supranutritional Se supplementation, DIO3 mRNA level was upregulated at $4.5 \mathrm{ppm}$ Se addition. Selenoprotein P and W1 gene expression were significantly upregulated by 1.5 and $4.5 \mathrm{ppm}$ Se supplementation, respectively. Thioredoxin reductase 1 gene expression was decreased by $4.5 \mathrm{ppm}$ Se. No appreciable differences in meat lipid oxidation were observed amongst treatments. So, feeding 1.5 ppm organic Se could be beneficial in improving humoral immune response to PPR vaccine and hepatic antioxidant status in lambs. Further, the expression of genes encoding selenoproteinases depends on their type and dose of Se in the diet. The studied Se doses did not induce toxicity in organs but exhibited limited potential to enhance meat oxidative stability.
\end{abstract}

\section{Introduction}

Selenium (Se), as an essential micronutrient for livestock, is needed for proper antioxidant defense, thyroid function, reproduction, immunity and health (Mehdi et al., 2013). Se intake in animals is greatly influenced by the geographical distribution (Haug et al., 2007) and many parts of the world such as Europe and Asia report Se deficiency in animals (Saha, 2017). Se deficiency is linked with oxidative stress, myodegeneration, hepatic degeneration and immunosuppression. At high doses Se is toxic 
and results in alkali disease and mortality (Zhan et al., 2007; Mehdi et al., 2013; Mehdi and Dufrasne, 2016). For small ruminants, the maximum tolerable level of Se is $5 \mathrm{mg} / \mathrm{kg}$ (as fed), beyond which toxicity occurs (NRC, 2007). Dietary supplementation of $\mathrm{Se}$ is on the rise since the issue of sub-optimal concentrations of $\mathrm{Se}$ is frequently encountered in standard diets of many countries. Commercially available Se supplements include the inorganic mineral salts such as sodium selenite or selenate, and organic forms such as Se-enriched yeast. Currently, Se yeast has become widely employed source of $\mathrm{Se}$ in animal nutrition (Fagan et al., 2015).

Peste des petits ruminants (PPR), identified as a transboundary animal disease by the World Organization of Animal Health (OIE) is an economically important contagious disease that poses a major threat to small ruminant production in endemic regions including India (Fakri et al., 2015). According to PPR Global Control and Eradication Strategy aiming to eradicate PPR by 2030 (OIE-FAO, 2015; Jones et al., 2016), improving immunity would be a better preventive strategy against PPR. Dietary Se yeast supplementation is demonstrated to improve antibody titre, neutrophil killing activity and reduce morbidity and mortality in weaned beef calves (Hall et al., 2013). In the recent studies dietary Se yeast that provided from 0.3 to $5 \mathrm{mg} \mathrm{Se} / \mathrm{kg}$ of diet (as fed) augmented immunity to pathogens, restored humoral and innate immune responses in foot-rot affected sheep (FDA, 2018; Hugejiletu et al., 2013), and enhanced resistance to naturally occurring Haemonchus contortus gastrointestinal parasitism in ewes (Hooper et al., 2014). Hence, we think that supplementation of Se at levels above 0.3 but less than $5 \mathrm{mg} / \mathrm{kg}$ of diet may enhance immune response to PPR vaccination in lambs, however it is not documented in small ruminants, especially in growing lambs, yet.

The biological functions of Se are mediated through selenoproteins that contain the $21^{\text {st }}$ proteinogenic amino acid, selenocysteine ( $\mathrm{Sec})$. The number of selenoprotein-coding genes varies amongst species, with mammals possessing from 24 to 25 (Mariotti et al., 2012). Major selenoproteins includes: glutathione peroxidases (GPXs), thioredoxin reductases (TXNRDs), iodothyronine dediodinases (DIOs), selenoprotein P (SEPP1), selenoprotein W (SEPW1) and $15-\mathrm{kDa}$ selenoprotein (SEP15; also called selenoprotein F (SELENEOF)). GPXs possess peroxidase activity and provide protection from reactive oxygen and nitrogen species. TXNRDs control various redox processes of the cell and DIOs regulate thyroid hormone metabolism. SEPP1 is the Se transport protein with an additional antioxidant function, while SEPW1 is involved in the regulation of cell cycle and redox function. SEP15 belongs to the $\mathrm{Rdx}$ family and is involved in redox functioning (Mehdi et al., 2013; Gladyshev et al., 2016). Given the importance of nutrigenomics, the influence of essential micronutrients on animal genomes and subsequently their health is receiving remarkable attention. Se is known to regulate expression of selenoprotein genes in response to changes in Se nutrition in laboratory animals (Hu et al., 2010; Sunde and Raines, 2011), poultry (Sun et al., 2011; Yuan et al., 2013) and pigs (Zhou et al., 2009). Nevertheless, the regulation of selenoprotein genes by organic Se in liver is not known in lambs.

Lipids present in meat undergo peroxidation. Though peroxidation is a normal process, it affects nutritional quality of meat and generates toxic compounds for humans (Gordon, 2001). Dietary antioxidant supplementation is attempted as a strategy to improve oxidative stability of meat (Zhan et al., 2007). The antioxidant effect of Se is recognized for its various biological functions. Supplementation of Se as selenized yeast is shown to inhibit oxidative processes in meat of pigs (Zhan et al., 2007) and broilers (Chen et al., 2014). However attempts to improve oxidative stability in lamb meat through dietary Se yeast supplementation up to $0.45 \mathrm{ppm}$ were not successful (Juniper et al., 2008; Vignola et al., 2009) and hence needs to be explored further with higher levels of Se. Such reduction in lipid oxidation in meat would be beneficial for sheep market and public health as sheep is a part of small ruminant sector that contributes to global food security and nutrition, specifically in developing countries like India (Birthal, 2002; Oliveira et al., 2014).

Therefore, the present study was conducted to evaluate the effect of dietary organic Se supplementation on immune response, hepatic antioxidant status, mRNA expression of major selenoproteins and oxidative stability of lamb meat.

\section{Material and methods}

\section{Chemicals and reagents}

All used chemicals were either analytical or of molecular biology grade and were purchased from Sigma-Aldrich (St. Louis, MO, USA), Hi-Media Laboratories (Mumbai, India) or Sisco Research laboratory Pvt. Ltd., Mumbai, India. 


\section{Animal housing and management}

Twenty male lambs of a local breed, aged 5-6 months were used for the study. The animals were maintained at the Experimental Livestock Unit of the Indian Council of Agricultural Research-National Institute of Animal Nutritonand Physiology (ICAR-NIANP), Bangalore (India). The lambs were housed individually in a well ventilated barn with separate feeding and water facilities. The experimental protocol was approved by the Committee for the Purpose of Control and Supervision of Experiments on Animals, Ministry of Environment, Forests and Climate Change, Government of India (S. No. 4./2015). Necessary prophylactic measures and protocols were adhered to protect animals from common bacterial and other ecto- and endo-parasitic infestations. The animals were acclimatized for two months prior to setting up of the experiment. During the entire period of the study, the health conditions of lambs were closely monitored for any possible injury and abnormal behaviour.

\section{Animal distribution and experimental diets}

The lambs were distributed by a completely randomized design into 4 dietary groups consisting of 5 lambs in each group. Animals were fed basal diet composed of concentrate mixture and finger millet straw (Eleusine coracana) in the 50:50 ratio. Diet was formulated to meet the nutrient requirements according to Indian Council of Agricultural Research (ICAR-NIANP, 2013) with the exception of Se. The ingredient composition of concentrate mixture of basal diet is shown in Table 1. The four dietary treatments were: basal diet (control), basal diet supplemented with $0.5 \mathrm{ppm} \mathrm{Se}$ (Se-0.5 group), $1.5 \mathrm{ppm} \mathrm{Se}$ (Se-1.5 group) and $4.5 \mathrm{ppm}$ Se (Se-4.5 group). The dose range of Se was selected in order to represent the minimum and maxiumum level of supplementation above the FDA permittted level of $0.3 \mathrm{mg} / \mathrm{kg}$ and below the maximum tolerable level of $5 \mathrm{mg} / \mathrm{kg}$ of diet (as fed), respectively. The organic Se source used in

Table 1. Ingredient composition of concentrate fed to experimental lambs, \%

\begin{tabular}{|c|c|}
\hline Ingredients & Content \\
\hline Maize & 38 \\
\hline Soybean meal & 15 \\
\hline Ground nut cake & 17 \\
\hline Wheat bran & 27 \\
\hline Mineral mixture ${ }^{1}$ & 2 \\
\hline Salt & 1 \\
\hline
\end{tabular}

the present study was SEL-PLEX 2000 (Alltech Biotechnology Private Limited, Bangalore, India) with the following characteristics: Saccharomyces cerevisiae strain: CNCM I-3060; organic Se in the form of selnomethionine: $63 \%$; low molecular weight selenocompounds: $35 \%$ and residual inorganic Se: $<3 \%$ (FEEDAP, 2011). Se was supplemented in concentrate and fed individually to animals on daily basis throughout 90-day experimental period. Each animal had free access to clean and fresh water on a daily basis.

\section{Estimation of basal Se in the experimental diets}

The basal Se content of concentrate mixture and forage fed (finger millet straw) were determined by Inductively Coupled Plasma Mass Spectrometryat Indian Institute of Food Processing Technology, Ministry of Food Processing Industries, Tamil Nadu (India), and found to be 0.018 and $0.003 \mathrm{ppm}$, respectively.

\section{Assessment of immune response}

After 69 days of experimental feeding, all lambs were vaccinated with Peste des petits ruminants (PPR) virus vaccine $\left(10^{3} \mathrm{TCID}_{50}\right)$. Blood samples were collected from jugular vein before and after 21 days from vaccination (the end of the trial). Serum was separated and antibody titre against PPR virus was determined by competitive enzyme linked immunosorbent assay kit of Indian Veterinary Research Institute, India (Singh et al., 2004).

\section{Collection of liver samples for antioxidant assay and gene expression analysis}

At the end of experiment, all lambs were sacrificed and liver samples were collected for antioxidant and gene expression analysis. About $5 \mathrm{~g}$ of tissue samples were stored immediately at $-80^{\circ} \mathrm{C}$ for antioxidant assays, whereas $1 \mathrm{~g}$ of tissue was dipped in RNA Later (Cat. No. AM7020; Invitrogen BioServices India Pvt. Ltd., Bangalore, India) and stored at $-80{ }^{\circ} \mathrm{C}$ until further analysis.

\section{Measurement of total antioxidant capacity}

Liver sample homogenates were prepared according to the procedure described by Luciano et al. (2011) and used to assess total antioxidant capacity according to Benzie and Strain (1996).

\section{Determination of relative expression of genes encoding selenoproteins in liver samples}

Designing of primers for the examined and reference genes. Primers for selenoprotein genes (Table 2) were designed using Primer 3 web tool 
Table 2. List of selected selenoprotein genes and endogenous control gene with their primers properties used in qPCR analysis

\begin{tabular}{|c|c|c|c|c|c|}
\hline Gene name & Accession No. & Primer sequence $\left(5^{\prime}-3^{\prime}\right)$ & & $\mathrm{Tm},{ }^{\circ} \mathrm{C}$ & $\begin{array}{l}\text { Amplicon size, } \\
\text { bp }\end{array}$ \\
\hline Glutathione peroxidase 1 (GPX1) & XM_004018462.4 & $\begin{array}{l}\text { GCTCTCCGGGGATTTTGCC } \\
\text { TGTGGTCTGGGAAAGGGGA }\end{array}$ & $\begin{array}{l}19 \\
19\end{array}$ & $\begin{array}{l}55.4 \\
53.3\end{array}$ & 127 \\
\hline Glutathione peroxidase 3 (GPX3) & XM_015096153.2 & $\begin{array}{l}\text { CAGGAAGAGCTTGAACCATTCG } \\
\text { TCGAACATACTTGAGGGTGGC }\end{array}$ & $\begin{array}{l}22 \\
21\end{array}$ & $\begin{array}{l}54.8 \\
54.4\end{array}$ & 114 \\
\hline Thioiredoxin reductase 1 (TXNRD1) X & XM_004006684.4 & $\begin{array}{l}\text { CTGAAGGCTTCTCAGGAAAGC } \\
\text { AGGTCGTAGTCATAGGGTTCC }\end{array}$ & $\begin{array}{l}21 \\
21\end{array}$ & $\begin{array}{l}54.4 \\
54.4\end{array}$ & 86 \\
\hline lodothyronine deiodinase 1 (DIO1) & XM_004001999.4 & $\begin{array}{l}\text { ATCCCTACCTTCTTCAGTGCC } \\
\text { CTTGCATGAAGTCCCAGATGC }\end{array}$ & $\begin{array}{l}21 \\
21\end{array}$ & $\begin{array}{l}54.4 \\
54.4\end{array}$ & 154 \\
\hline lodothyronine deiodinase 3 (DIO3) & NM_001122650.1 & $\begin{array}{l}\text { GCGCCTAACTCTGAGGTGG } \\
\text { TCGCGCTGATACTTGGTGAC }\end{array}$ & $\begin{array}{l}19 \\
20\end{array}$ & $\begin{array}{l}55.4 \\
53.8\end{array}$ & 167 \\
\hline $\begin{array}{l}\text { 15-kDa selenoprotein like protein } \\
\text { (SEP15)/selenoprotein F (SELENOF) }\end{array}$ & XM_004002164.4 & $\begin{array}{l}\text { AGCACAGCCCATGATAGGTAAG } \\
\text { CCACAAGTCTACTACCAGGCATT }\end{array}$ & $\begin{array}{l}22 \\
24\end{array}$ & $\begin{array}{l}54.8 \\
57.4\end{array}$ & 107 \\
\hline Selenoprotein P1 (SEPP1) & XM_027980091.1 & $\begin{array}{l}\text { CGGAAGGGGTTCTGACAAC } \\
\text { GCTCTCTGTTCCTCCGGTTAG }\end{array}$ & $\begin{array}{l}19 \\
21\end{array}$ & $\begin{array}{l}53.3 \\
56.3\end{array}$ & 89 \\
\hline Selenoprotein W1 (SEPW1) & XM_004023205.3 & $\begin{array}{l}\text { TGTTTACTATGGCGCTTGAGG } \\
\text { CCCGCTACGAACACTTCAAAG }\end{array}$ & $\begin{array}{l}21 \\
21\end{array}$ & $\begin{array}{l}52.4 \\
54.4\end{array}$ & 141 \\
\hline $\begin{array}{l}\text { Glyceraldehyde-3-phosphate dehy- } \\
\text { drogenase (GAPDH) }\end{array}$ & NM_001190390.1 & $\begin{array}{l}\text { AGGAGCACGAGAGGAAGAGAG } \\
\text { TGAGGATGGAAATGTATGGAG }\end{array}$ & $\begin{array}{l}21 \\
21\end{array}$ & $\begin{array}{l}60 \\
55\end{array}$ & 100 \\
\hline
\end{tabular}

(http://primer3.ut.ee/). The relative mRNA abundances of 7 genes encoding selenoproteins were assayed in all the groups. The examined genes included: glutathione peroxidase 1 (GPX1), glutathione peroxidase 3 (GPX3), iodothyronine deiodinase 1 (DIO1), iodothyronine deiodinase 3 (DIO3), thioredoxin reductase 1 (TXNRD1), selenoprotein P1 (SEPP1), 15-kDa selenoprotein like protein (SEP15) and selenoprotein W1 (SEPW1). Glyceraldehyde-3-phosphate dehydrogenase (GAPDH) was used as the endogenous control gene.

\section{RNA isolation and cDNA synthesis}

Total RNA from liver samples was isolated using TRIReagent BD (Sigma-Aldrich, St. Louis, MO, USA) and cleaned up using RNeasy Mini Kit (QIAGEN India Pvt. Ltd., New Delhi, India). The RNA quality and quantity were determined by measuring the absorbance at 260 and $280 \mathrm{~nm}$ using the NanoDrop-ND 2000C spectrophotometer (Thermo Fisher Scientific, Waltham, MA, USA) and checking the integrity of total RNA by agarose gel electrophoresis. cDNA was synthesized from total RNA by reverse transcription using Transcriptor First Strand cDNA Synthesis Kit (Roche Diagnostics India Pvt. Ltd., Mumbai, India) and stored at $-80^{\circ} \mathrm{C}$ until further use.

\section{Real-Time PCR assay}

The expression of the target genes was measured by SYBR green based Real-Time PCR assay relative to GAPDH as the endogenous control gene. The efficiency of the endogenous control and target genes assays was determined in 5-folds serially diluted cDNA template starting from $50 \mathrm{ng}$ to $0.4 \mathrm{ng}$ in duplicate with no template control (NTC) and negative reversed transcription control (10 ng of total RNA) run in triplicate. The PCR amplification of endogenous control and target genes in actual samples was performed in triplicate in $10 \mu 1$ of reaction mixture which contained: $0.5 \mu 1$ of each forward and reverse primers $(02.5 \mu \mathrm{M})$, $5 \mu 1$ of $2 \times$ Faststart SYBR Green master mix (Cat. No. 6924204001, Roche Diagnostics India Pvt. Ltd., Mumbai, India) and $4 \mu 1$ (10 ng) of cDNA for the samples (+RT) or $4 \mu \mathrm{l}(10 \mathrm{ng})$ of total RNA for negative reverse transcriptase control (-RT) or $4 \mu 1$ of PCR grade water for NTC, respectively. The PCR reaction was conducted with the use of Light Cycler $^{\circledR} 480$ instrument (Roche Diagnostics, Basel, Switzerland). The PCR cycling conditions were comprised of: $95{ }^{\circ} \mathrm{C}$ for $3 \mathrm{~min}$ for initial denaturation followed by 50 cycles of $95{ }^{\circ} \mathrm{C}$ for $15 \mathrm{~s}$ (denaturation), $60{ }^{\circ} \mathrm{C}$ for $30 \mathrm{~s}$ (annealing) and $72{ }^{\circ} \mathrm{C}$ for $15 \mathrm{~s}$ (extension). The melt curve analysis condition consisted of: 1-min initial denaturation at $95{ }^{\circ} \mathrm{C}$, annealing at $55^{\circ} \mathrm{C}$ and melting at $55-95^{\circ} \mathrm{C}$ for $10 \mathrm{~s}$. The GAPDH expression was measured in the samples and was used to normalize the variations in the amount of target genes mRNA in all samples. The relative mRNA abundance of target genes in tissue samples was determined by the method of Livak and Schmittgen (2001) in which, 
the $\Delta \mathrm{C}_{\mathrm{q}}$ value is the difference between the target and reference gene $\left(\Delta \mathrm{Cq}=\mathrm{Cq}_{\text {target }}-\mathrm{Cq}_{\text {reference }}\right)$. For each of the target genes, the normalized relative expression was calculated with use of method, where $\Delta \Delta \mathrm{C}_{\mathrm{T}}=\Delta \mathrm{C}_{\mathrm{T}}$ sample $-\Delta \mathrm{C}_{\mathrm{T}}$ control. PCR reaction of each sample was conducted in triplicate.

\section{Histology of tissues}

Immediately after sacrifice, samples of liver, kidney, thymus and spleen were collected, placed in $10 \%$ formalin and then processed and stained with haematoxylin and eosin (Bancroft and Stevens, 1996) with some modifications. The obtained histological preparations were observed under light microscope (Eclipse 80i, Nikon, Shisuka, Japan).

\section{Determination of Se in liver}

The Se content in liver was quantified using Inductively Coupled Plasma Optical Emission Spectrometry (Optima $^{\mathrm{TM}}$ 8000, Perkin Elmer Inc, Waltham, MA, USA) by the method of Fallah et al. (2011). analysis of variance (ANOVA) followed by Duncan's multiple range post hoc test for antioxidant assay and by Tukey's post hoc test for immune study. The effects were considered significant at $P \leq 0.05$. Data on gene expression were subjected to one-way ANOVA analysis followed by post hoc LSD test to compare the difference between control and Se-supplemented groups. In gene expression analysis, significance level was set at $P \leq 0.05$. Results are presented as means \pm standard error of mean (SE).

\section{Results}

\section{Immune response in PPR vaccinated lambs}

The PPR antibody titre quantified on day 0 of vaccination showed no significant difference between lambs of control group and Se supplemented groups. However, on day 21 after vaccination increased values of PPR antibody titre anlysis were observed in Se-1.5 and Se-4.5 groups compared to control one. In contrast, no significant difference was observed between Se-0.5 and control groups (Table 3).

Table 3. The PPR antibody titre in serum of control and selenium supplemented lambs

\begin{tabular}{llllll}
\hline $\begin{array}{l}\text { PPR antibody titre, \% } \\
\text { inhibition }\end{array}$ & Groups $^{1}$ & & & & \multirow{2}{*}{$P$-value } \\
\cline { 2 - 5 } Control & Se-0.5 & Se-1.5 & Se-4.5 & \\
Day 0 & $18.2 \pm 1.23$ & $17.5 \pm 1.01$ & $15.0 \pm 1.06$ & $16.1 \pm 0.83$ & 0.183 \\
Day 21 & $74.9 \pm 0.80^{c}$ & $76.9 \pm 2.38^{\text {bc }}$ & $82.9 \pm 2.97^{\text {ab }}$ & $85.4 \pm 1.55^{\mathrm{a}}$ & 0.014 \\
\hline
\end{tabular}

${ }^{1}$ Groups: control - basal diet, Se-0.5 - basal diet + 0.5 ppm Se, Se-1.5 - basal diet + 1.5 ppm Se, Se-4.5 - basal diet + 4.5 ppm Se; ${ }^{a b c}$ - means with different superscripts within a row are significantly different $(P \leq 0.05)$; values represent means \pm standard error

\section{Storage studies}

At $24 \mathrm{~h}$ post-mortem, from each individual lamb, longissimus dorsi (LD) muscle was sampled and stored at $4{ }^{\circ} \mathrm{C}$. Before storage and after 3, 7 and 10 days of storage, lipid oxidation status was measured by determining malondialdehyde (MDA) level according to Luciano et al. (2011).

\section{Statistical analyses of data}

Data generated from antioxidant assays and immune response study were analysed by Statistical Package for Social Sciences (SPSS, version 18.0, 2010; SPSS Inc., Chicago, IL, USA) by one-way

\section{Hepatic antioxidant status}

Hepatic total antioxidant capacity of lambs fed diet supplemented with $0.5 \mathrm{ppm}$ Se did not differ from the control one. On the other hand, hepatic total antioxidant capacity was significantly higher $(P<0.05)$ in lambs fed diet supplemented with 1.5 and $4.5 \mathrm{ppm}$ Se in comparison to control animals (Table 4).

\section{Relative mRNA expression of specific selenoprotein genes}

In comparison to control animals, hepatic GPX1 and GPX3 mRNA expression was significantly upregulated $(P<0.05)$ in lambs fed diet supplemented

Table 4. Total antioxidant activity in the liver of control and selenium supplemented lambs

\begin{tabular}{|c|c|c|c|c|c|}
\hline \multirow{2}{*}{ Indices } & \multicolumn{4}{|l|}{ Groups $^{1}$} & \multirow{2}{*}{$P$-value } \\
\hline & control & Se-0.5 & Se-1.5 & Se-4.5 & \\
\hline $\begin{array}{l}\text { FRAP }^{2}, \text { mg gallic acid } \\
\text { equivalents (GAE)/g liver }\end{array}$ & $19.69 \pm 0.92^{b}$ & $20.23 \pm 2.17^{b}$ & $35.35 \pm 3.16^{a}$ & $30.02 \pm 3.50^{a}$ & 0.001 \\
\hline
\end{tabular}


with $0.5 \mathrm{ppm}$ Se. However, there was no difference in GPX1 and GPX3 mRNA expressions between Se-1.5 or Se-4.5 group and control one (Figure 1). The hepatic TXNRD1 mRNA expression was similar in control, Se- 0.5 and Se-1.5 groups; however, it was downregulated $(P<0.05)$ in Se-4.5 group as compared to the control one (Figure 2). The expression of hepatic DIO1 did not differ significantly between control and Se supplemented groups (Figure 3). However, DIO3 mRNA expression was increased $(P<0.05)$ in lambs fed diet supplemented with $4.5 \mathrm{ppm}$ Se but not in $\mathrm{Se}-0.5$ and Se- 1.5 groups in comparison to the control

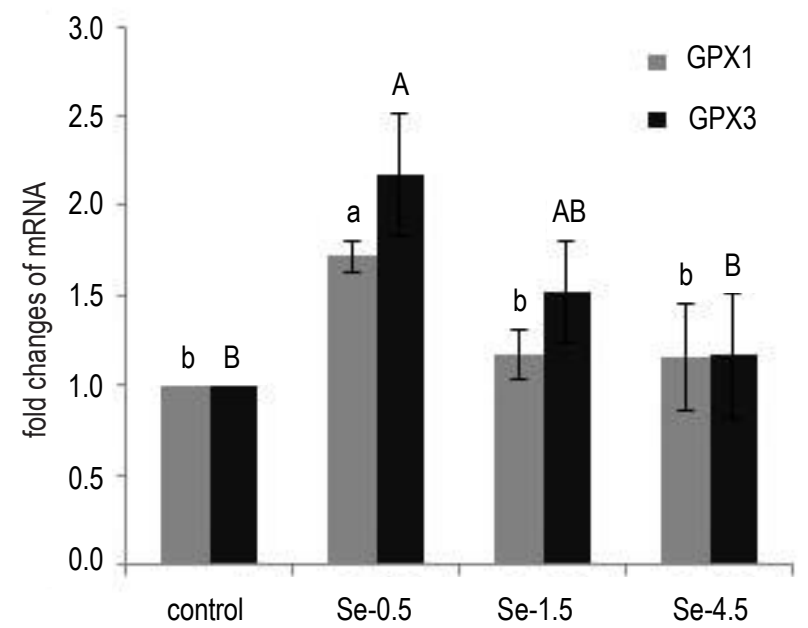

Figure 1. The relative gene expression of glutathione peroxidase 1 (GPX1) and 3 (GPX3) in liver of control and selenium suppplemented lambs

The fold change of expression was calculated using the formula of Livak and Schmittgen (2001) and normalized against the expression of control values; values represent means \pm standard error; ab and $A B$ - bars with different superscripts for each gene seperately are significantly different $(P<0.05)$

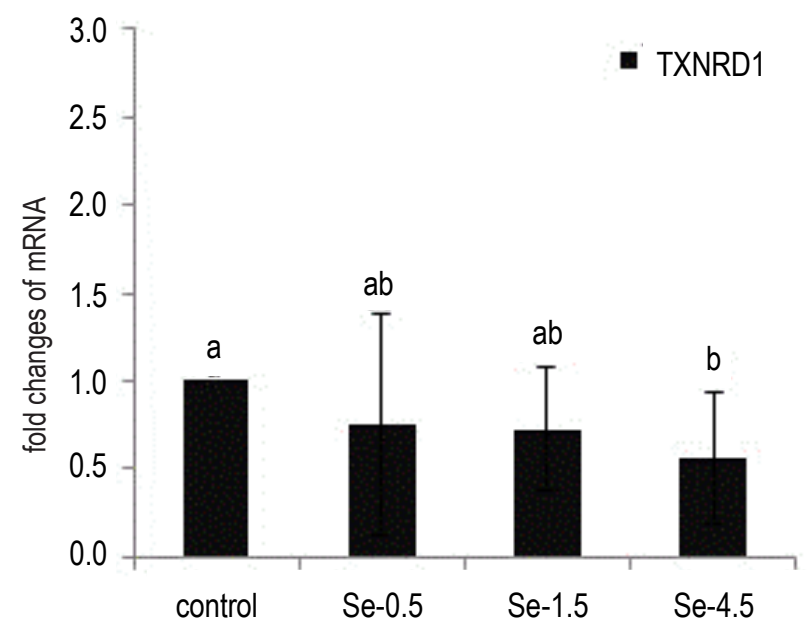

Figure 2. The relative gene expression of hepatic thioredoxin reductase 1 (TXNRD1) in liver of control and selenium suppplemented lambs

Values represent means \pm standard error; ab - bars with different superscripts are significantly different $(P<0.05)$ one (Figure 3). Supplementation of $1.5 \mathrm{ppm}$ Se into lamb diet increased $(P<0.05)$ hepatic SEPP1 mRNA levels. However, the higher $(4.5 \mathrm{ppm})$ and lower $(0.5 \mathrm{ppm})$ Se addition did not affect the expression of this gene as compared to control (Figure 4). The expression of SEPW1 did not change when diet was supplemented with $0.5 \mathrm{ppm}$ Se; however $1.5 \mathrm{ppm}$ supplementation resulted in down-regulation and $4.5 \mathrm{ppm}$ caused up-regulation of this gene in comparison to the control group. None of the levels of Se used in the present study affected the hepatic SEP15 mRNA expression in lamb liver.

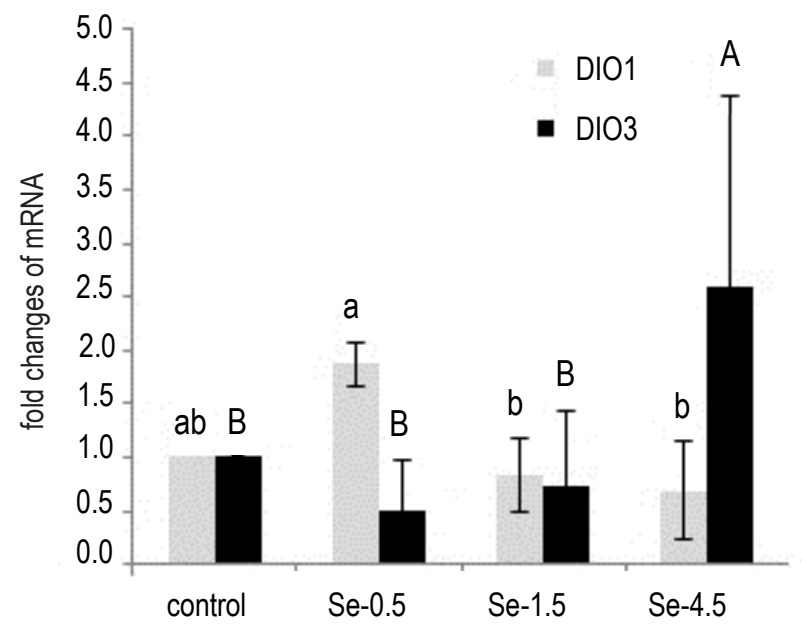

Figure 3. The relative gene expression of iodothyronine deiodinase 1 (DIO1) and 3 (DIO3) in liver of control and selenium suppplemented lambs

Values represent means \pm standard error; $a b$ and $A B$ - bars with different superscripts for each gene seperately are significantly different $(P<0.05)$

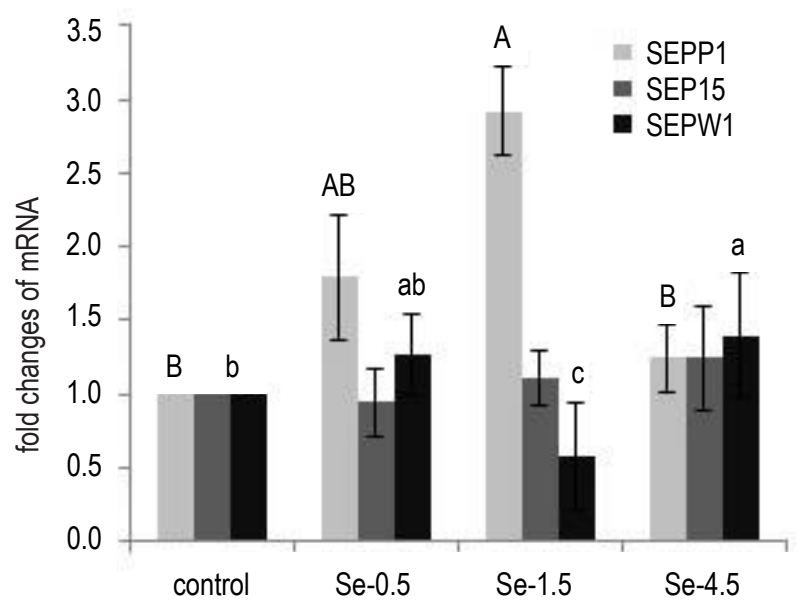

Figure 4. The relative gene expression of selenoprotein P (SEPP1), selenoprotein W1 (SEPW1) and 15-kDa selenoprotein 15 (SEP15) in liver of control and selenium suppplemented lambs

Values represent means \pm standard error; $a b$ and $A B$ - bars with different superscripts for each gene seperately are significantly different $(P<0.05)$ 


\section{Histology of vital organs and Se liver content}

Microscopic observations of liver, kidney, spleen and thymus of control, Se-0.5, Se-1.5 and Se4.5 groups showed normal architecture without any adverse changes. The liver tissues exhibited normal architecture with hepatocytes arranged in radiating cords like pattern from the central vein (Figure 5). The average Se content in liver of lambs fed control and Se supplemented diets $(0.5,1.5$ and $4.5 \mathrm{ppm} \mathrm{Se})$ was $124,47.308,35.65$ and $68.6 \mathrm{ppb}$, respectively.

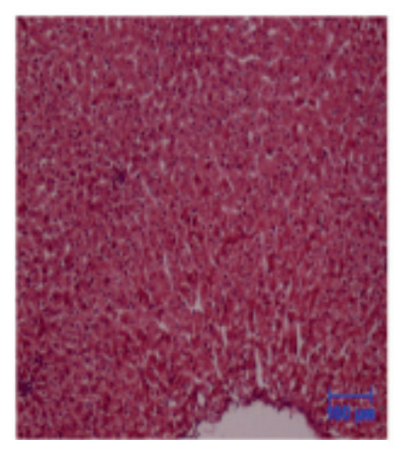

control

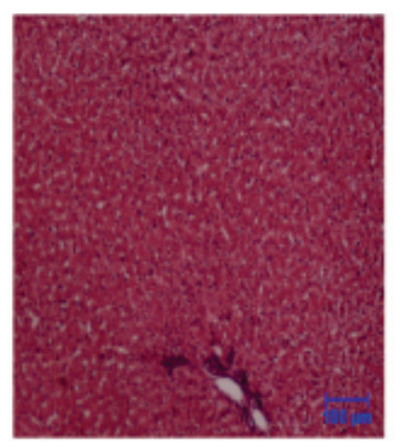

Se-1.5 Scale:100 $\mu \mathrm{m}$

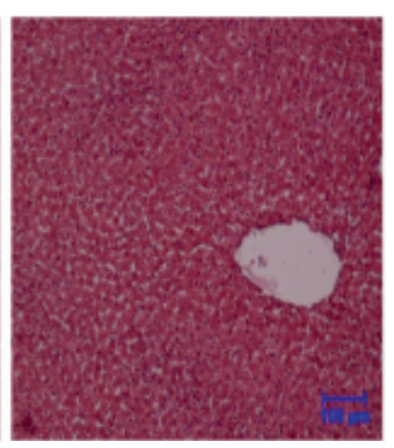

Se- 0.5

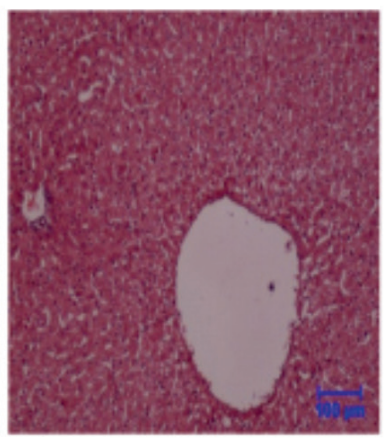

Se-4.5
Figure 5. Histology of liver of control and experimental animals Groups: control - basal diet, Se- 0.5 - basal diet $+0.5 \mathrm{ppm}$ Se, Se-1.5 - basal diet + $1.5 \mathrm{ppm} \mathrm{Se}$, Se-4.5 - basal diet + $4.5 \mathrm{ppm} \mathrm{Se}$; haematoxylin and eosin staining

\section{Oxidative stability of stored meat}

Before storage (day 0) the MDA levels in meat from lambs fed diet supplemented with 1.5 and
$4.5 \mathrm{ppm}$ Se were significantly lower $(P<0.001)$ as compared to meat from animals fed control diet. However, on days 3, 7 and 10 of storage, no significant difference was observed amongst groups (Table $5)$.

\section{Discussion}

Peste des petits ruminants (PPR) is an acute, contagious and common fatal disease of sheep and goats, caused by a morbillivirus. To control and eradicate PPR, vaccination is considered as the best method, especially in countries in which controlling animal movement is difficult (Jones et al., 2016). In the present study an enhancement in immune response to PPR vaccine was observed in lambs fed diet supplemented with 1.5 and $4.5 \mathrm{ppm}$ Se. In line with the results of current study, Hall et al. (2011) reported improved humoral response to vaccination with a J-5 Escherichia coli bacterin in adult beef cows fed Se supplemented feed. Inspite of the established immune enhancing potential of $\mathrm{Se}$, the detailed mechanism of Se mediating this function remains unknown. However, the improved immune response observed herein could be linked to up-regulation of lymphocyte protein biosynthesis genes, enhanced lymphocyte function (Pagmantidis et al., 2008) and enrichment of several immune system-related biological processes (Elgendy et al., 2016). In addition to enhanced immune response, in our study the fact that feeding diet supplemented with 1.5 and $4.5 \mathrm{ppm}$ Se improved hepatic antioxidant capacity was revealed. These findings are in agreement with the study of Yue et al. (2009) who reported improved antioxidant status in goats fed diets supplemented with 0.349 to $0.5496 \mathrm{mg} / \mathrm{kg}$ DM of selenomethionine. Since the hepatic antioxidant system plays a major role in mammalian health (Juszczuk-Kubiak et al., 2016), the augmented antioxidant activity observed in these animals has a greater physiological significance in protecting against oxidative stress.

Table 5. Lipid oxidation expressed as thiobarbituric acid reactive substances (TBARS) before (day 0) and on day 3, 7 and 10 of storage in longissiums dorsi muscles of control and selenium supplemented lambs

\begin{tabular}{|c|c|c|c|c|c|}
\hline \multirow{2}{*}{$\begin{array}{l}\text { TBARS, mg MDA/kg } \\
\text { meat }\end{array}$} & \multicolumn{4}{|l|}{ Groups $^{1}$} & \multirow{2}{*}{$P$-value } \\
\hline & control & Se- 0.5 & Se-1.5 & Se-4.5 & \\
\hline Day 0 & $0.48 \pm 0.08^{a}$ & $0.60 \pm 0.10^{a}$ & $0.18 \pm 0.02^{b}$ & $0.19 \pm 0.02^{b}$ & 0.001 \\
\hline Day 3 & $0.86 \pm 0.14$ & $0.63 \pm 0.09$ & $0.53 \pm 0.09$ & $0.57 \pm 0.08$ & 0.169 \\
\hline Day 7 & $1.1 \pm 0.20$ & $0.78 \pm 0.13$ & $0.60 \pm 0.10$ & $0.63 \pm 0.06$ & 0.206 \\
\hline Day 10 & $1.19 \pm 0.09$ & $1.49 \pm 0.33$ & $1.03 \pm 0.17$ & $1.05 \pm 0.14$ & 0.378 \\
\hline
\end{tabular}

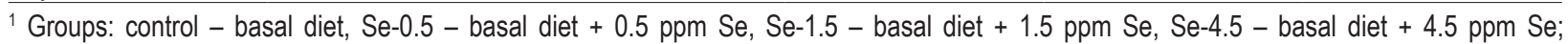
MDA - malondialdehyde; ${ }^{a b}$ - means with different superscripts within a row are significantly different $(P \leq 0.01)$; values represent means \pm standard error 
Liver is the major organ primarily involved in processing of dietary Se for transport, distribution to other tissues and for excretion. Liver is more responsive than other tissues, such as longissimus dorsi muscle, to dietary Se supplementation (JuszczukKubiak et al., 2016). In the present study, hepatic selenoprotein gene expression showed three patterns, i.e. increased, decreased and unaltered expression in response to organic Se supplementation. The observed changes in expression is supportive of the fact that some selenoproteins are more sensitive to a specific dose in comparison to others (Fairweather-Tait et al., 2011).

GPX1 is the cytosolic antioxidant selenoprotein ubiquitously expressed in all cells and its promoter possesses an oxygen responsive element. GPX1 converts endogenously formed reactive oxygen species such as hydroperoxides and hydrogen peroxide $\left(\mathrm{H}_{2} \mathrm{O}_{2}\right)$ to their corresponding alcohols and thereby offers protection against oxidative damage (Stoytcheva and Berry, 2009; Zhang et al., 2013). GPX3 is the only extracellular antioxidant GPX enzyme. GPX3 promoter possess functional consensus site for the redox regulated transcription factor activator protein 1 in the 5'-region, a novel transcription start site, functional stimulating protein 1 (sp1), hypoxia-inducible factor-1 binding sites and as well as redox sensitive ARE/EpRE and putative metal response element (Stoytcheva and Berry, 2009). In the current study, both hepatic GPX1 and GPX3 genes were found to be up-regulated by $0.5 \mathrm{ppm}$ Se supplementation, suggesting their response to dietary Se. However, in our experiment it was shown that supplementing diet with 1.5 and $4.5 \mathrm{ppm}$ Se did not influence GPX1 mRNA expression. During limited Se supply, GPX1 mRNA are highly susceptible to nonsense mediated decay (NMD) and their levels are regulated by this mechanism rather than the transcriptional regulation process (Stoytcheva and Berry, 2009). Since NMD, is a post-transcriptional mechanism that regulates gene expression in eukaryotic cells (Han et al., 2018), the possibility of existence of a similar mechanism during exposure to 1.5 and $4.5 \mathrm{ppm}$ Se needs to be explored. Although $\mathrm{H}_{2} \mathrm{O}_{2}$ is linked with oxidative stress, it is as an important signaling molecule involved in regulation of number of biological processes and pathways such as cell proliferation, apoptosis, stress response, and mitochondria-related functions. Though GPX1 counteracts the damaging effects of $\mathrm{H}_{2} \mathrm{O}_{2}$ overexpression of GPX1 leads to stress reduction stress and disruption of $\mathrm{H}_{2} \mathrm{O}_{2}$ signalling (Labunsky et al., 2014). Therefore, it is clear that the absence of changes in GPX1 mRNA levels in liver of lambs fed diets sup- plemented with 1.5 and $4.5 \mathrm{ppm}$ Se is a protective trend exhibited by the biological system. With respect to GPX3, its regulation occurs primarily at the translation stage (Zhang et al., 2013), thus ascertaining the unchanged GPX3 gene expression pattern in lambs fed diet with 1.5 and $4.5 \mathrm{ppm}$ Se addition.

Being expressed ubiquitously, mammalian TXNRDs works in combination with thioredoxin to maintain redox balance inside cells. TXNRD1 controls a number of physiological processes such as antioxidant defense, regulation of transcription factors, and apoptosis (Mehdi et al., 2013). Though feeding diet with 0.5 and $1.5 \mathrm{ppm}$ Se did not induce significant changes, in the present study changes in TXNRD1 mRNA levels in lambs fed diet supplemented with $4.5 \mathrm{ppm}$ Se were revealed. Stoytcheva and Berry (2009) have reported that TXNRD1 mRNA levels are post-transcriptionally modulated via a cluster of AU rich motifs located in the 3'-UTR of the TXNRD1 mRNA. Although thyroxine is produced and released from thyroid, the hepatic DIO1 is most important in catalyzing the circulating thyroxine to the more active 3,5,3,-tri-iodothyronine (T3) (Arthur et al., 1990) and DIO1 is highly expressed in liver (Stoytcheva and Berry, 2009). On the other hand, DIO3 catalyzes the inactivation of the active thyroid hormone T3 by sequentially removing iodine groups. Differences in DIO1 and DIO3 mRNA expression observed in our study indicate that Se influence different DIO gene expression in an independent way.

The up-regulation in SEPP1 mRNAexpression in lambs fed diet supplemented with $1.5 \mathrm{ppm}$ Se is reported in this study. Interestingly, this group exhibited highest mRNA abundance, across the dose of Se and selenoprotein genes studied in this experiment. Our results reinforce that liver is the major source of plasma selenoprotein $\mathrm{P}$ which is transported and taken up by other target organs through an APOER2 receptor mediated process for selenoprotein biosynthesis (Juszczuk-Kubiak et al., 2016).The highest SEPP1 mRNA could be associated with the improved antioxidant capacity observed in Se-1.5 group as SEPP1 is an effective antioxidant (Mehdi et al., 2013). Strikingly, SEPP1 mRNA showed no alterations in lambs from Se-4.5 group, indicating insensitivity of this gene to higher levels of Se. In our study up-regulation of SEPW1 mRNA by lambs feeding with diet supplemented with $4.5 \mathrm{ppm}$ Se was observed. Our results are in agreement with previous reports concerning beef heifers fed $3.0 \mathrm{mg}$ Se/day for 168 days (Matthews et al., 2014). SEPW1 specifically binds to glutathione and removes reactive oxygen species such as $\mathrm{H}_{2} \mathrm{O}_{2}$, superoxide anion radical, and hydroxyl 
radical and thereby functions as an antioxidant (Mariotti et al., 2012). Thus the improved hepatic antioxidant capacity observed in Se-4.5 group in the current investigation reinforces the antioxidant function of SEPW1 (Sun et al., 2011). However, the observed down-regulation of SEPW1 in 1.5-Se group appears to be unique. Therefore, it is possible that, in addition to transcriptional regulation, various post-transcriptional mechanisms may be involved in its regulation. Indeed, SP family of transcription factors and specifically SP1, are suggested to bind to various regulatory sequences of the SEPW1 promoter to activate or repress transcription of SEPW1 gene (Stoytcheva and Berry, 2009). SEP15 is known to function as thioldisulphide isomerase that is involved in disulphide bond formation (Sun et al., 2011) and as antioxidant (Mehdi et al., 2013). Studies on SEP15 gene in ruminants are limited. Therefore the absence of change in hepatic SEP15 mRNA expression due to Se supplementation in the present study unveil a new dimension on the regulation of SEP15 by dietary Se.

Se concentration in liver is sensitive to changes in dietary Se and excess Se is stored in liver, kidney, heart, immune organs and muscles (Zhang et al., 2013). Previous studies reported doubling of hepatic Se concentrations in goats fed diet supplemented with 0.3 ppm organic Se as compared to control animals fed 0.03 ppm Se (Shi et al., 2011) and in broilers fed $0.45-0.6 \mathrm{ppm}$ organic Se compared to birds fed 0.15 ppm Se (Oliveira et al., 2014). Davis et al. (2008) reported elevated liver Se levels in wether sheep fed diet supplemented with high doses of 20, 30 and 40 ppm organic Se as compared to controls fed $0.2 \mathrm{mg} \mathrm{Se} / \mathrm{kg}$. Though organic Se-supplemented animals exhibited higher Se liver content than controls, a proportional or dose-dependent increase with respect to dietary Se was not observed and in animals fed $30 \mathrm{mg} / \mathrm{kg}$ highest liver Se concentrations amongst all treatments was recorded. Similarly, in the present study, Se levels in control group were the highest and a dose-dependent increase in liver Se concentrations with increasing dietary Se was not observed in lambs fed diet supplemented with 0.5, 1.5 and $4.5 \mathrm{ppm}$ Se. Such a trend implies the possible operation of a specialized homeostatic mechanism in sheep supplemented with organic Se above 0.3 ppm levels and is a future area of investigation.

No Se toxicity symptoms such as hair loss, fragility of fingernails or hooves, gastrointestinal upsets, skin rashes and/or unpleasant 'garlic' odour in exhaled air (dimethylselenide) (Kieliszek and Błażejak, 2016) were observed in the study. To assess if the different doses of Se used in the present study induce any toxic effects, histology of organs was studied. The liver samples of Se supplemented lambs did not show any pathological changes in the cell architecture and these findings are further supported by limited Se accumulation in the liver. In line with the current findings, no gross and pathological changes were reported in liver tissue of wether lambs fed diets up to $\leq 10 \mathrm{ppm}$ dietary Se as selenite for one year (Cristaldi et al., 2005). Similar to liver, kidney, thymus and spleen tissues showed normal architecture, indicating that no toxicity developed up to dose of $4.5 \mathrm{ppm}$ organic Se in this study. Oxidative stability of meat is related to lipid peroxidation in meat. Lipid peroxidation, a natural phenomenon that occurs in meat is a major cause of quality deterioration of meat and its products. Malondialdehyde (MDA), one of the end products of lipid peroxidation is a widely accepted marker of lipid peroxidation (Vignola et al., 2009). In a recent study, Czauderna et al. (2018) have observed reduction in lipid peroxidation in longisimus dorsi muscle of lambs fed diets enriched with rapeseed oil and fish oil supplemented with Se along with another antioxidant - carnosic acid. Previously, Zhan et al. (2007) observed reduced MDA content in pork from pigs fed diet supplemented with Se and attributed the advantageous results to the antioxidant effect of Se. The results of present study showed no appreciable differences in MDA content in meat after 3, 7 and 10 days of storage and are in line with the findings of Vignola et al. (2009). Thus it is reasonable to suggest to not consider dietary $\mathrm{Se}$ as a probable mode to improve oxidative stability of meat, specifically in lambs.

\section{Conclusions}

Dietary supplementation of organic selenium (Se) at the dose of $1.5 \mathrm{ppm}$ to growing lambs seems to be an efficient strategy to enhance immune response to Peste des petits ruminants vaccine as well as to increase the antioxidant status of liver without inducing negative effects on histology. Further, expression of genes encoding selenoproteins depends on their type and dose of Se in the diet. The study further demonstrated that supplementation of organic Se even up to $4.5 \mathrm{ppm}$ may not be helpful to enhance oxidative stability of meat, specifically in lambs.

\section{Acknowledgments}

We thankfully acknowledge Director of the institute for providing the necessary inputs and facilities to carry out this study. 


\section{References}

Arthur J.R., Nicol F., Beckett G.J., 1990. Hepatic iodothyronine 5'-deiodinase. The role of selenium. Biochem. J. 272, 537-540, https://doi.org/10.1042/bj2720537

Bancroft J.D., Stevens A. (Editors), 1996. Theory and Practice of Histological Techniques. $4^{\text {th }}$ Edition.Churchill Livingstone. London (UK)

Benzie I.F.F., Strain J.J., 1996. The ferric reducing ability of plasma (FRAP) as a measure of "antioxidant power": the FRAP assay. Anal. Biochem. 239, 70-76, https://doi.org/10.1006/ abio.1996.0292

Birthal P.S., 2002. Technological change in India's livestock subsector: evidence and issues. In: P.S. Birthal and P. Parthasarathy Rao (Editors). Technology Options for Sustainable Livestock Production in India. National Centre for Agricultural Economics and Policy Research, New Delhi (India), International Crops Research Institute for the Semi-Arid Tropics, Patancheru, Andhra Pradesh (India) and International Livestock Research Institute, Addis Ababa (Ethiopia), pp. 20-40

Chen G., Wu J., Li C., 2014. Effect of different selenium sources on production performance and biochemical parameters of broilers. J. Anim. Physiol. Anim. Nutr. 98, 747-754, https://doi. org/10.1111/jpn.12136

Cristaldi L.A., McDowell L.R., Buergelt C.D., Davis P.A., Wilkinson N.S., Martin F.G., 2005. Tolerance of inorganic selenium in wether sheep. Small Rumin. Res. 56, 205-213, https://doi. org/10.1016/j.smallrumres.2004.06.001

Czauderna M., Ruszczyńska A., Bulska A., Krajewska K.A., 2018. Seleno-compounds and carnosic acid added to diets with rapeseed and fish oils affect concentrations of selected elements and chemical composition in the liver, heart and muscles of lambs. Biol. Trace Elem. Res. 184, 378-390, https:// doi.org/10.1007/s12011-017-1211-z

Davis P.A., McDowell L.R., Wilkinson N.S., Buergelt C.D., Van Alstyne R., Weldon R.N., Marshall T.T., Matsuda-Fugisaki E.Y., 2008. Comparative effects of various dietary levels of Se as sodium selenite or Se yeast on blood, wool, and tissue Se concentrations of wether sheep. Small Ruminant Res. 74, 149-158, https://doi.org/10.1016/j.smallrumres.2007.05.003

Elgendy R., Giantin M., Castellani F., Grotta L., Palazzo F., Dacasto M., Martino G., 2016. Transcriptomic signature of high dietary organic selenium supplementation in sheep: A nutrigenomic insight using a custom microarray platform and gene set enrichment analysis. J. Anim. Sci. 94, 3169-3184, https:// doi.org/10.2527/jas.2016-0363

Fagan S., Owens R., Ward P., Connolly C., Doyle S., Murphy R., 2015. Biochemical comparison of commercial selenium yeast preparations. Biol. Trace Elem. Res. 166, 245-259, https:// doi.org/10.1007/s12011-015-0242-6

Fairweather-Tait S.J., Bao Y., Broadley M.R., Collings R., Ford D., Hesketh J.E., Hurst R., 2011. Selenium in human health and disease. Antioxid. Redox Signal. 14, 1337-1383, https://doi. org/10.1089/ars.2010.3275

Fakri F., Ghzal F., Daouam S., Elarkam A., Douieb L., Zouheir Y., Tadlaoui K., Fassi-Fihri O., 2015. Development and field application of a new combined vaccine against Peste des Petits Ruminants and Sheep Pox. Trials Vaccinol. 4, 33-37, https:// doi.org/10.1016/j.trivac.2015.03.004

Fallah A.A., Saei-Dehkordi S.S., Nematollahi A., Jafari T., 2011. Comparative study of heavy metal and trace element accumulation in edible tissues of farmed and wild rainbow trout (Oncorhynchus mykiss) using ICP-OES technique. Microchem. J. 98, 275-279, https://doi.org/10.1016/..microc.2011.02.007
FDA (Food and Drug Administration), 2018. Code of Federal Regulations Title 21 - Food and Drugs; Chapter 1 - Food and Drug Administration, Department of Health and Human Services; Subchapter E - Animal drugs, feeds, and related products; Part 573 - Food additives permitted in feed and drinking water of animals; Subpart B - Food Additive Listing; Section 573.920 - Selenium (21CFR573.920), https://www. accessdata.fda.gov/scripts/cdrh/cfdocs/cfcfr/CFRSearch. $\mathrm{cfm}$ ?fr $=573.920$

FEEDAP (EFSA Panel on Additives and Products or Substances used in Animal Feed), 2011. Scientific opinion on safety and efficacy of Sel-Plex ${ }^{\circledR}$ (organic form of selenium produced by Saccharomyces cerevisiae CNCM I-3600) for all species. EFSA J. 9, 2110, https://doi.org/10.2903/j.efsa.2011.2110

Gladyshev V.N., Arnér E.S., Berry M.J. et al., 2016. Selenoprotein gene nomenclature. J. Biol. Chem. 291, 24036-24040, https://doi.org/10.1074/jbc.M116.756155

Gordon M.H., 2001. The development of oxidative rancidity. In: J. Pokorny, N. Yanishlieva, M.H. Gordon (Editors). Antioxidants in Food: Practical Applications.Woodhead Publishing Limited. Cambridge (UK), pp. 7-21, https://doi. org/10.1016/9781855736160.1.5

Hall J.A., Harwell A.M., Van Saun R.J., Vorachek W.R., Stewart W.C., Galbraith M.L., Hooper K.J., Hunter J.K., Mosher W.D., PireIli G.J., 2011. Agronomic biofortification with selenium: Effects on whole blood selenium and humoral immunity in beef cattle. Anim. Feed Sci. Technol. 164, 184-190, https://doi. org/10.1016/j.anifeedsci.2011.01.009

Hall J.A., Vorachek W.R., Stewart W.C., Gorman M.E., Mosher W.D., Pirelli G.J., Bobe G., 2013. Selenium supplementation restores innate and humoral immune responses in footrot-affected sheep. PLOS ONE 8, e82572, https://doi.org/10.1371/ journal.pone. 0082572

Han X., Wei Y., Wang H., Wang F., Ju Z., Li T., 2018. Nonsense-mediated mRNA decay: a 'nonsense' pathway makes sense in stem cell biology. Nucleic Acids Res. 46, 1038-1051, https:// doi.org/10.1093/nar/gkx1272

Haug A., Graham R.D., Christophersen O.A., Lyons G.H., 2007. How to use the world's scarce selenium resources efficiently to increase the selenium concentration in food. Microb. Ecol. Health Dis. 19, 209-228, https://doi. org/10.1080/08910600701698986

Hooper K.J., Bobe G., Vorachek W.R., Bishop-Stewart J.K., Mosher W.D., Pirelli G.J., Kent M.L., Hall J.A., 2014. Effect of selenium yeast supplementation on naturally acquired parasitic infection in ewes. Biol. Trace Elem. Res. 161, 308-317, https://doi.org/10.1007/s12011-014-0134-1

Hu Y., McIntosh G.H., Le Leu R.K., Young G.P., 2010. Selenium-enriched milk proteins and selenium yeast affect selenoprotein activity and expression differently in mouse colon. Br. J. Nutr. 104, 17-23, https://doi.org/10.1017/S0007114510000309

Hugejiletu H., Bobe G., Vorachek W.R., Gorman M.E., Mosher W.D., Pirelli G.J., Hall J.A., 2013. Selenium supplementation alters gene expression profiles associated with innate immunity in whole-blood neutrophils of sheep. Biol. Trace Elem. Res. 154, 28-44, https://doi.org/10.1007/s12011-013-9716-6

ICAR-NIANP (Indian Council of Agricultural Research-National Institute of Animal Nutrition and Physiology), 2013. Nutrient Requirements of Animals - Sheep, Goat and Rabbit. ICARNIANP, New Delhi (India)

Jones B.A., Rich K.M., Mariner J.C., Anderson J., Jeggo M., Thevasagayam S., Cai Y., Peters A.R., Roeder P., 2016. The economic impact of eradicating peste des petits ruminants: a benefit-cost analysis. PLoS ONE 11, e0149982, https://doi. org/10.1371/journal.pone.0149982 
Juniper D.T., Phipps R.H., Givens D.I., Jones A.K., Green C., Bertin G., 2008. Tolerance of ruminant animals to high dose in-feed administration of a selenium-enriched yeast. J. Anim. Sci. 86, 197-204, https://doi.org/10.2527/jas.2006-773

Juszczuk-Kubiak E., Bujko K., Cymer M., Wicińska K., Gabryszuk M., Pierzchała M., 2016. Effect of inorganic dietary selenium supplementation on selenoprotein and lipid metabolism gene expression patterns in liver and loin muscle of growing lambs. Biol. Trace Elem. Res. 172, 336-345, https://doi.org/10.1007/ s12011-015-0592-0

Kieliszek M., Błażejak S., 2016. Current knowledge on the importance of selenium in food for living organisms: a review. Molecules 21, 609, https://doi.org/10.3390/molecules21050609

Labunsky V.M., Hatfield D.L., Gladyshev V.N., 2014. Selenoproteins: molecular pathways and physiological roles. Physiol. Rev. 94, 739-777, https://doi.org/10.1152/physrev.00039.2013

Livak K.J., Schmittgen T.D., 2001. Analysis of relative gene expression data using Real-Time Quantitative PCR and the method. Methods 25, 402-408, https://doi.org/10.1006/meth.2001.1262

Luciano G., Vasta V., Monahan F.J., López-Andrés P., Biondi L., Lanza M., Priolo A., 2011. Antioxidant status, colour stability and myoglobin resistance to oxidation of longissimus dorsi muscle from lambs fed a tannin-containing diet. Food Chem. 124, 1036-1042, https://doi.org/10.1016/j.foodchem.2010.07.070

Mariotti M., Ridge P.G., Zhang Y., Lobanov A.V., Pringle T.H., Guigo R., Hatfield D.L., Gladyshev V.N., 2012. Composition and evolution of the vertebrate and mammalian selenoproteomes. PLOS ONE 7, e33066, https://doi.org/10.1371/journal.pone.0033066

Matthews J.C., Zhang Z., Patterson J.D., Bridges P.J., Stromberg A.J., Boling J.A., 2014. Hepatic transcriptome profiles differ among maturing beef heifers supplemented with inorganic, organic, or mixed (50\% inorganic: $50 \%$ organic) forms of dietary selenium. Biol. Trace Elem. Res. 160, 321-339, https://doi.org/10.1007/ s12011-014-0050-4

Mehdi Y., Dufrasne I., 2016. Selenium in cattle: A review. Molecules 21 545, https://doi.org/10.3390/molecules21040545

Mehdi Y., Hornick J.-L, Istasse L., Dufrasne I., 2013. Selenium in the environment, metabolism and involvement in body functions. Molecules 18, 3292-3311, https://doi.org/10.3390/ molecules 18033292

NRC (National Research Council), 2007. Nutrient Requirements of Small Ruminants: Sheep, Goats, Cervids, and New World Camelids. The National Academies Press. Washington, DC (USA), https://doi.org/10.17226/11654

OIE-FAO (World Organisation for Animal Health-Food and Agriculture Organization of United Nations), 2015. Global Strategy for the Control and Eradication of PPR. OIE (Paris, France) and FAO (Rome, Italy)

Oliveira T.F.B., Rivera D.F.R., Mesquita F.R., Braga H., Ramos E.M., Bertechini A.G., 2014. Effect of different sources and levels of selenium on performance, meat quality, and tissue characteristics of broilers. J. Appl. Poult. Res. 23, 15-22, https://doi.org/10.3382/japr.2013-00761
Pagmantidis V., Méplan C., van Schothorst E.M., Keijer J., Hesketh J.E., 2008. Supplementation of healthy volunteers with nutritionally relevant amounts of selenium increases the expression of lymphocyte protein biosynthesis genes. Am. J. Clin. Nutr. 87, 181-189, https://doi.org/10.1093/ajcn/87.1.181

Saha U.K., 2017. Selenium: a vital element in soil-pant-animal/human continuum. J. Agric. Sci. Bot. 1, 1-3

Shi L., Xun W., Yue W., Zhang C., Ren Y., Shi L., Wang Q., Yang R., Lei F., 2011. Effect of sodium selenite, Se-yeast and nano-elemental selenium on growth performance, Se concentration and antioxidant status in growing male goats. Small Ruminant Res. 96, 49-52, https://doi.org/10.1016/j.smallrumres.2010.11.005

Singh R.P., Sreenivasa B.P., Dhar P., Shah L.C., Bandyopadhyay S.K., 2004. Development of a monoclonal antibody based competitive-ELISA for detection and titration of antibodies to peste des petits ruminants (PPR) virus. Vet. Microbiol. 98, 3-15, https://doi.org/10.1016/j.vetmic.2003.07.007

Stoytcheva Z.R., Berry M.J., 2009. Transcriptional regulation of mammalian selenoprotein expression. Biochim. Biophys. Acta 1790, 1429-1440, https://doi.org/10.1016/j.bbagen.2009.05.012

Sun B., Wang R., Li J., Jiang Y., Xu S., 2011. Dietary selenium affects selenoprotein $W$ gene expression in the liver of chicken. Biol. Trace Elem. Res. 143, 1516-1523, https://doi.org/10.1007/ s12011-011-8995-z

Sunde R.A., Raines A.M., 2011. Selenium regulation of the selenoprotein and nonselenoprotein transcriptomes in rodents. Adv. Nutr. 2, 138-150, https://doi.org/10.3945/an.110.000240

Yuan D., Zheng L., Guo X.Y., Wang Y.X., Zhan X.A., 2013. Regulation of selenoprotein $\mathrm{P}$ concentration and expression by different sources of selenium in broiler breeders and their offspring. Poult. Sci. 92, 2375-2380, https://doi.org/10.3382/ps.201303155

Yue W., Zhang C., Shi L., Ren Y., Jiang Y., Kleemann D.O., 2009. Effect of supplemental selenomethionine on growth performance and serum antioxidant status in Taihangblack goats. AsianAustralas. J. Anim. Sci. 22, 365-370, https://doi.org/10.5713/ ajas.2009.80474

Vignola G., Lambertini L., Mazzone G., Giammarco M., Tassinari M., Martelli G.,Bertin G., 2009. Effects of selenium source and level of supplementation on the performance and meat quality of lambs. Meat Sci. 81, 678-685, https://doi.org/10.1016/j. meatsci.2008.11.009

Zhan X.A., Wang M., Zhao R.Q., Li W.F., Xu Z.R., 2007. Effects of different selenium source on selenium distribution, loin quality and antioxidant status in finishing pigs. Anim. Feed Sci. Technol. 132, 202-211, https://doi.org/10.1016/j.anifeedsci.2006.03.020

Zhang L., Zhou Z., Li G., Fu M., 2013. The effect of deposition Se on the mRNA expression levels of gpxs in goats from a Se-enriched county of China. Biol. Trace Elem. Res. 156, 111-123, https:// doi.org/10.1007/s12011-013-9830-5

Zhou J.-C., Zhao H., Li J.-G., Xia X.-J., Wang K.-N., Zhang Y.-J., Liu Y., Zhao Y., Lei X.G., 2009. Selenoprotein gene expression in thyroid and pituitary of young pigs is not affected by dietary selenium deficiency or excess. J. Nutr. 139, 1061-1066, https://doi.org/10.3945/jn.109.104901 